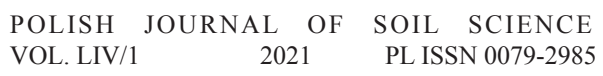

DOI: $10.17951 / \mathrm{pjss} / 2021.54 .1 .59$

\title{
RADKA BOZHINOVA*, TSVETA HRISTEVA* \\ SOIL FERTILITY IN RESPONSE TO LONG-TERM FERTILIZATION UNDER THE TOBACCO MONOCULTURE SYSTEM ON RENDZIC LEPTOSOL IN BULGARIA
}

Abstract. The effect of long-term mineral and organic-mineral fertilization on selected soil properties $(\mathrm{pH}$, total humus and $\mathrm{N}$, available phosphorus, potassium, calcium, magnesium, iron and manganese content) was studied in a stationary trail with tobacco monocropping system. The trial was established on Rendzic Leptosols in 1966. Five treatments were selected for this study, including control without fertilization (Check), nitrogen + phosphorus (NP), nitrogen + potassium (NK), nitrogen + phosphorus + potassium $(\mathrm{NPK})$ and nitrogen + phosphorus + potassium + manure (NPK + manure). Soil samples at a depth of $0-25 \mathrm{~cm}$ were collected from all studied plots every year (2014, 2015 and 2016). The results indicated that maintaining humus content at the initial level is not possible through yearly mineral fertilizer application. Long-term mineral phosphorus fertilization increased 5.5-5.7 times available $\mathrm{P}_{2} \mathrm{O}_{5}$ in the soil compared to the initial level. The soil available $\mathrm{K}_{2} \mathrm{O}$ content in NK and NPK treatments increased, respectively, by $41.1 \%$ and $44.9 \%$ over the initial level. A remarkable increase in available phosphorus (25.5 times) and potassium (2.5 times) content in the soil compared with the initial level was found due to longterm NPK + manure fertilization. The NPK + manure treatment was found to be the most efficient management system in accumulating of total humus and $\mathrm{N}$, available $\mathrm{P}_{2} \mathrm{O}_{5}, \mathrm{~K}_{2} \mathrm{O}, \mathrm{Fe}$ and $\mathrm{Mn}$ in a long-term fertilized Rendzic Leposol, under a tobacco monocropping system.

Keywords: long-term fertilization, total humus, nitrogen, available nutrients

* Agricultural Academy, Tobacco and Tobacco Products Institute, BG-4108 Markovo, Bulgaria. Corresponding author: rbojinova@yahoo.com 


\section{INTRODUCTION}

Fertilization is an important human-controllable factor for producing good yield and quality of tobacco. There are numerous questions about the impact of the long-term fertilization on soil properties and crop productivity. Long-term field experiments provide indispensable sources of knowledge that can help in answering them. Such experiments are important in monitoring, understanding and providing proofs for the changes in soil fertility occurring as a result of long-term agrotechnical interventions, most importantly - of fertilization (Debreczeni and Körschens 2003).

Soil $\mathrm{pH}$ is accepted as a dominant factor that regulates soil nutrient bioavailability. Mineral and organic fertilization proved to be one of the factors causing soil acidification (Vašák et al. 2015). Soil organic carbon (SOC) is a strong determinant of chemical, physical, and biological properties, and soil quality. Shevtsova et al. (2003) reported that the mineral fertilization contributes significantly to the formation of labile humic substances at the expense of Ca-forms of soil organic matter which are more resistant to microbial decomposition and act as the binding agents of aggregate stability. The data of Hati et al. (2007) showed that long-term application of balanced fertilizer alone or in conjunction with farmyard manure (FYM) induced a clear increase in organic carbon status of the soil and consequently helped in carbon sequestration in the soil. In comparison with unfertilized control and treatments with inorganic fertilizers, farmyard manure significantly increased soil organic carbon and total $\mathrm{N}$ concentrations in the $0-30 \mathrm{~cm}$ layer (Liang et al. 2012). When the humus content in ordinary chernozem is $43.5-45.2 \mathrm{~g} \cdot \mathrm{kg}^{-1}$, it is necessary to introduce manure at a rate of 6.7-8.0 t $\cdot \mathrm{ha}^{-1}$ annually to maintain its balance deficit-free (Goryanin et al. 2019). Merbach et al. (2000) concluded that in the long term, the $\mathrm{C}$ - and N-contents of the soil largely depend on the amount of hardly decomposable organic matter applied with organic fertilization. The same authors found that high mineral $\mathrm{N}$ doses, with consequent high crop and root residues, also increased the humus content in the soil.

For optimal crop yield, sufficient available phosphorus, potassium, calcium, magnesium and micronutrients are required. Annual additions of inorganic fertilizers for 22 years increased extractable $\mathrm{P}$ and exchangeable $\mathrm{K}$ in topsoil. This effect was generally enhanced with manure application (Yang et al. 2007). Nutrient concentrations in the soil (the Magruder Plots) showed that relative to the fertilized plots, application of manure increased calcium and magnesium levels (Edmeades 2003). Long-term application of organic fertilizers as well as organic fertilizers with additional phosphorus and potassium fertilization led to an increase in the content of $\mathrm{Ca}^{2+}+\mathrm{Mg}^{2+}+\mathrm{K}^{+}+\mathrm{Na}^{+}$in the sorption complex (Mazur et al. 2015). The availability of micronutrients in the soil can strongly affect yields and quality of crops. It was shown that the DTPA-extractable soil 
$\mathrm{Fe}$ and $\mathrm{Mn}$ concentrations increased with increasing soil organic matter content, thus, demonstrating the importance of soil organic matter in micronutrient availability for crops. The NPK treatment also had higher DTPA-extractable micronutrient concentrations in soil (Li et al. 2007).

This paper reports the effects of different long-term fertilization treatments (mineral and organic-mineral fertilization) on soil properties $-\mathrm{pH}$, total humus and $\mathrm{N}$, available phosphorus, potassium, calcium, magnesium, iron and manganese content - in a tobacco monocropping system.

\section{MATERIALS AND METHODS}

\section{Field experimental conditions}

The three-year data (2014-2016) were obtained from a trial with long-term fertilization. The trial was established as a stationary experiment with continuous tobacco cropping system established in 1966 at the Tobacco and Tobacco Products Institute - Markovo, Bulgaria ( $42^{\circ} 06^{\prime} \mathrm{N}$ and $\left.24^{\circ} 70^{\prime} \mathrm{E}\right)$. It includes twenty-eight different treatments of fertilization with various rates and combinations of nitrogen, phosphorus and potassium. In addition, organic-mineral fertilization has been tested. The nitrogen fertilization rates applied are $0,25,50$, and $100 \mathrm{~kg} \cdot \mathrm{ha}^{-1}$, for phosphorus $-0,50,75,100$, and $225 \mathrm{~kg} \cdot \mathrm{ha}^{-1}$, and for potassium $-0,75$, and $450 \mathrm{~kg} \cdot \mathrm{ha}^{-1}$. Since 1966 , the experimental design is maintained as a randomized complete block replicated three times. The soil is classified as Rendzic Leptosol (World Reference Base for Soil Resources) (Teoharov 2004).

The growing season for tobacco at this location is often characterized by warm and dry summers. Oriental tobacco plants (Nicotiana tabaccum L. cv. Plovdiv 7) were grown in the stationary field. The plot area was $6.25 \mathrm{~m}^{2}(2.5 \times$ $2.5 \mathrm{~m})$. Tobacco seedlings were transplanted at a $0.5 \times 0.12 \mathrm{~m}$ distance $(166,000$ plants $\left.\cdot \mathrm{ha}^{-1}\right)$.

\section{Treatments}

Five of the above treatments were selected for this study, including control without fertilization (Check), nitrogen + phosphorus (NP), nitrogen + potassium $(\mathrm{NK})$, nitrogen + phosphorus + potassium $(\mathrm{NPK})$ and nitrogen + phosphorus + potassium + manure $(\mathrm{NPK}+$ manure). The fertilizer application rates of the treatments are shown in Table 1. 
Table 1. Treatments and annual fertilizer application rates $\left(\mathrm{kg} \cdot \mathrm{ha}^{-1} \cdot \mathrm{year}^{-1}\right)$

\begin{tabular}{ccccc}
\hline \multirow{2}{*}{ Treatments } & \multicolumn{5}{c}{ Fertilizers } \\
\cline { 2 - 5 } & Nitrogen $(\mathrm{N})$ & Phosphorus The & $\begin{array}{c}\text { Potassium } \\
\left(\mathrm{K}_{2} \mathrm{O}\right)\end{array}$ & Manure \\
\hline Check & - & - & - & - \\
\hline NP & 50 & 75 & - & - \\
\hline NK & 50 & - & 75 & - \\
\hline NPK & 50 & 75 & 75 & - \\
\hline NPK + manure & 50 & 75 & 75 & 20,000 \\
\hline
\end{tabular}

Urea, triple superphosphate and potassium sulphate were used as sources of $\mathrm{N}, \mathrm{P}$ and K. Manure came from cattle farms. Fertilizers were broadcast before transplanting and then incorporated in the topsoil layer. At the beginning of the experiment, the soil had a $\mathrm{pH}$ value of 8.50 and contained $3.01 \%$ humus, $15 \mathrm{mg}$ available $\mathrm{P}_{2} \mathrm{O}_{5} \cdot \mathrm{kg}^{-1}$ soil and $400-500 \mathrm{mg}$ available $\mathrm{K}_{2} \mathrm{O} \cdot \mathrm{kg}^{-1}$ soil as described in the first formal publication of its soil properties (Vartanyan 1979).

\section{Soil sampling and analysis}

In March, soil samples at a depth of 0-25 cm were collected from all studied plots every year (2014, 2015 and 2016). The following soil characteristics were determined: $\mathrm{pH}$ in water (1:1), humus according to Tjurin (Totev et al. 1987), total $\mathrm{N}$ - by the Kjeldahl method, available $\mathrm{P}_{2} \mathrm{O}_{5}-$ by the Egner-Riehm method, available $\mathrm{K}_{2} \mathrm{O}-$ in $2 \mathrm{~N} \mathrm{HCl}$. Available $\mathrm{Ca}$ and $\mathrm{Mg}$ were determined by using $1 \mathrm{~N} \mathrm{KCl}$ (Tomov et al. 1999). A solution of $0.005 \mathrm{M}$ diethylentriaminepentaacetic acid (DTPA) and 0.1 M triethanolamine (TEA) buffered at $\mathrm{pH} 7.3$ was used for extraction of the Fe and Mn mobile forms from soil (Lindsay and Norvell 1978).

An atomic absorption spectrometer SpectrAA 220 (Varian, Australia) was used for determination of $\mathrm{K}, \mathrm{Ca}, \mathrm{Mg}, \mathrm{Fe}$ and $\mathrm{Mn}$ content in the soil samples at the following wavelengths: $\mathrm{K}-766.5 \mathrm{~nm}, \mathrm{Ca}-422.7 \mathrm{~nm}, \mathrm{Mg}-285.2 \mathrm{~nm}, \mathrm{Fe}-$ $248.3 \mathrm{~nm}$ and $\mathrm{Mn}-279.5 \mathrm{~nm}$.

\section{Statistical analysis}

Results were analyzed using the SPSS statistical package, and differences were assessed with the Duncan's multiple range test at the 0.05 probability level. 


\section{RESULTS AND DISCUSSION}

\section{Soil $p H$, total humus and $N$}

Soil $\mathrm{pH}$ varied from 7.91 to 8.18 , depending on the treatment (Table 2). After continuous fertilization, the soil reaction was slightly decreased, which indicates its strong $\mathrm{pH}$ buffer capacity. The $\mathrm{pH}$ in mineral fertilizer treatments declined by 0.32 to 0.37 units compared to the initial status. The decrease in $\mathrm{pH}$ in the mineral fertilizer plots might be attributed to the nitrification and acidification processes stimulated by continuous application of fertilizers as well as by $\mathrm{H}^{+}$released by roots. Merbach et al. (2000) reported that continuous use of physiologically acid, neutral and alkaline fertilizers (i.e. $\mathrm{N}$ applied as ammonium, amide, or nitrate) in this order have a declining effect on the acid-base balance of the soil. The data from our long-term experiment showed that by comparison with the control, soil $\mathrm{pH}$ values were unaffected by the addition of inorganic fertilizers. Significant differences were identified between the control plot and NPK + manure applications. The soil $\mathrm{pH}$ in the NPK + manure treatment was 7.91, which was 0.59 units lower than the initial value. Our results correspond to the findings of Šimek et al. (1999), who reported that in the absence of lime, the effect of manure combined with inorganic fertilizers was to reduce soil $\mathrm{pH}$. According to Wei et al. (2006), the decrease in soil pH in the NP + manure treatments might have resulted from the release of organic acids and $\mathrm{CO}_{2}$ into the soil during the decomposition of manure. In our experiment the soil $\mathrm{pH}$ in plots without fertilization was 0.33 units lower than the initial value. Debreczeni and Kismányoky (2005) also reported that the soil acidification is occurring on the zero NPK plots probably because of leaching and plant uptake of basic cations and possibly because of environmental pollution.

Table 2. Soil pH and content of total humus (\%) and total N (\%) as dependent on long-term fertilization (3-year average)

\begin{tabular}{cccc}
\hline Treatments & $\mathrm{pH}$ & Total humus & Total N \\
\hline Check & $8.17^{\mathrm{a}}$ & $2.48^{\mathrm{d}}$ & $0.143^{\mathrm{d}}$ \\
\hline $\mathrm{NP}$ & $8.13^{\mathrm{a}}$ & $2.73^{\mathrm{bc}}$ & $0.161^{\mathrm{c}}$ \\
\hline $\mathrm{NK}$ & $8.18^{\mathrm{a}}$ & $2.64^{\mathrm{cd}}$ & $0.156^{\mathrm{c}}$ \\
\hline $\mathrm{NPK}$ & $8.14^{\mathrm{a}}$ & $2.86^{\mathrm{b}}$ & $0.172^{\mathrm{b}}$ \\
\hline NPK + manure & $7.91^{\mathrm{b}}$ & $4.38^{\mathrm{a}}$ & $0.258^{\mathrm{a}}$ \\
\hline
\end{tabular}

The numerical values followed by a different letter in the superscript in a row are significantly different at $(p \leq 0.05)$ by Duncan's Multiple Range Test.

In our plots, NP, NPK and NPK + manure treatments significantly increased the humus content when compared to non-fertilized treatment (Table 2). The greatest accumulation of total humus was observed in the NPK + manure 
treatment. Šimek et al. (1999) concluded that the increases in soil C content were probably due to the combined effects of $\mathrm{C}$ addition with the manure and increased plant productivity as a result of both manure and inorganic fertilizer applications.

In terms of sustainability, our data showed that the NPK + manure treatment increased the humus content by $45.4 \%$ from $3.01 \%$ measured at the beginning of the experiment in 1966. This is in accordance with the results of Hati et al. (2007), who found that the soil organic carbon content in $100 \%$ NPK + FYM treatment increased, by $56.3 \%$ over the initial level. The humus depletion was $5.0 \%$ to $12.2 \%$ with mineral fertilizers, and by $17.7 \%$ in the control plot as compared to the initial value. According to Ellmer et al. (2000), the rate of organic matter depletion differs according to the cropping and tillage system, climate and soil. The same authors reported that in the control treatment and in the treatment with mineral fertilizer only, the organic carbon content decreased by $20 \%$ to $30 \%$. The data from our long-term experiment with continuous tobacco cropping system showed that maintaining humus content at the initial level is not possible through yearly mineral fertilizer application. These results are similar to the findings of Tomov and Artinova (2005) and to the study of Lenart et al. (2007), who demonstrated that continuous cropping without fertilization or long-term mineral fertilization decreased soil organic matter. On the other hand, Hati et al. (2007) found that the SOC status in unfertilized plots showed no decline even after 28 years of cropping, because of the crop residues left by soybean $\left(0.9 \mathrm{Mg} \cdot \mathrm{ha}^{-1} \cdot\right.$ year $\left.^{-1}\right)$ and wheat $\left(1.2 \mathrm{Mg} \cdot \mathrm{ha}^{-1} \cdot \mathrm{year}^{-1}\right)$ that might have assisted in maintaining the SOC level in control.

It was previously reported that the changes in soil humus content resulted in changes in the total nitrogen content and were strongly positively correlated to total organic $\mathrm{C}$ and total nitrogen content (Nardi et al. 2004, Tomov and Artinova 2005). In our experiment the application of fertilizers significantly increased soil $\mathrm{N}$ content compared with the control plot (Table 2). The plots receiving the $\mathrm{NPK}+$ manure treatment had higher total nitrogen content when compared with the other treatments. Results from our study are in agreement with the findings of Nardi et al. (2004), who reported that the $\mathrm{N}$ content varies with the $\mathrm{N}$ origin: when organic inputs are used, its release is slow and its availability persists for a long time. On the contrary, $\mathrm{N}$ added with mineral fertilizers is readily available but is subjected to faster leaching and uptake.

\section{Content of available nutrients in soil}

Continuous phosphorus fertilization significantly increased available $\mathrm{P}_{2} \mathrm{O}_{5}$ when compared to non-fertilized plot (Table 3). By comparing the initial soil phosphorus content in 1966 with phosphorus content for the period studied, it was observed that there was considerable buildup of phosphorus in the plots, which 
received $\mathrm{P}$ applications continuously. The available phosphorus was highest in the treatment with NPK + manure. Bhattacharyya et al. (2015) also reported that 42 years of FYM + NPK fertilizer application in flooded tropical rice in India caused the greatest increase in soil available $\mathrm{P}$ content. When $\mathrm{P}$ input from fertilizer exceeds $\mathrm{P}$ depletion by the crop, $\mathrm{P}$ accumulates in soil over time (Kuo et al. 2005). The data from our long-term trial showed annual increases of available $\mathrm{P}_{2} \mathrm{O}_{5}$ of $1.36 \mathrm{mg} \cdot \mathrm{kg}^{-1}$ with the NP treatment, $1.40 \mathrm{mg} \cdot \mathrm{kg}^{-1}$ with the NPK treatment and 7.3 $\mathrm{mg} \cdot \mathrm{kg}^{-1}$ with the application of NPK + manure. Sun et al. (2018) found that for the control, $\mathrm{N}$ and NK treatments, the Olsen-P concentrations declined by between 0.46 and $0.73 \mathrm{mg} \mathrm{P} \cdot \mathrm{kg}^{-1}$ soil $\cdot$ year ${ }^{-1}$, whereas for the P-containing treatments the rates of increase ranged from 1.68 to $17.5 \mathrm{mg} \mathrm{P} \cdot \mathrm{kg}^{-1}$ soil $\cdot$ year ${ }^{-1}$, depending on the $\mathrm{P}$ balance. According to Medinski et al. (2018), crop cultivation without P fertilization in control and NK treatments resulted in negative $\mathrm{P}$ balances and reduction of available $\mathrm{P}$ below recommended levels. The observed phosphorus content in the plots without $\mathrm{P}$ addition (Check and NK) was slightly higher than the initial value of $15 \mathrm{mg} \cdot \mathrm{kg}^{-1}$ soil. The data of Vartanyan (1979) also showed that the available phosphorus content in Check and NK treatments was slightly increased which was explained by $\mathrm{P}$ mobilization by roots exudates.

Table 3. Content of available $\mathrm{P}_{2} \mathrm{O}_{5}, \mathrm{~K}_{2} \mathrm{O}, \mathrm{Ca}, \mathrm{Mg}, \mathrm{Fe}$ and $\mathrm{Mn}$ in soil $\left(\mathrm{mg} \cdot \mathrm{kg}^{-1}\right)$ as dependent on long-term fertilization (3-year average)

\begin{tabular}{ccccccc}
\hline Treatments & $\mathrm{P}_{2} \mathrm{O}_{5}$ & $\mathrm{~K}_{2} \mathrm{O}$ & $\mathrm{Ca}$ & $\mathrm{Mg}$ & $\mathrm{Fe}$ & $\mathrm{Mn}$ \\
\hline $\mathrm{Check}$ & $27.4^{\mathrm{c}}$ & $442.3^{\mathrm{c}}$ & $3343^{\mathrm{a}}$ & $388^{\mathrm{a}}$ & $6.6^{\mathrm{b}}$ & $31.9^{\mathrm{b}}$ \\
\hline $\mathrm{NP}$ & $83.1^{\mathrm{b}}$ & $352.4^{\mathrm{d}}$ & $3516^{\mathrm{a}}$ & $316^{\mathrm{bc}}$ & $6.1^{\mathrm{b}}$ & $35.3^{\mathrm{b}}$ \\
\hline $\mathrm{NK}$ & $20.9^{\mathrm{c}}$ & $635.0^{\mathrm{b}}$ & $3456^{\mathrm{a}}$ & $288^{\mathrm{bc}}$ & $6.2^{\mathrm{b}}$ & $32.9^{\mathrm{b}}$ \\
\hline $\mathrm{NPK}$ & $85.0^{\mathrm{b}}$ & $652.0^{\mathrm{b}}$ & $3333^{\mathrm{a}}$ & $277^{\mathrm{c}}$ & $6.7^{\mathrm{b}}$ & $39.9^{\mathrm{b}}$ \\
\hline $\mathrm{NPK}+$ manure & $381.8^{\mathrm{a}}$ & $1126.7^{\mathrm{a}}$ & $3289^{\mathrm{a}}$ & $327^{\mathrm{b}}$ & $8.5^{\mathrm{a}}$ & $56.6^{\mathrm{a}}$ \\
\hline
\end{tabular}

The numerical values followed by a different letter in the superscript in a row are significantly different at $(p \leq 0.05)$ by Duncan's Multiple Range Test

Soil available $\mathrm{K}_{2} \mathrm{O}$ varied significantly among the treatments (Table 3). The lowest amount of available potassium content was found under the NP treatment. Results obtained in a long-term experiment under jute-rice-wheat cropping system showed that the application of $100 \%$ NP to soils resulted in a greater negative $\mathrm{K}$ balance than that from the unfertilized control (Mazumdar et al. 2014). The potassium content in the NPK + manure treatment was significantly higher compared to its values in all other treatments. The increase in available $\mathrm{K}$ with the application of NPK in addition to organic manure may be explained by mineralization of organic sources and solubilization from native sources during the decomposition (Mazumdar et al. 2014). In our study, the K content in control plot remained essentially unchanged from the initial level of $450.0 \mathrm{mg} \cdot \mathrm{kg}^{-1}$ soil. According to Jouany et al. (1996), exchangeable K content on non-fertilized 
plots declined slightly over the experimental period, but without reaching levels expected from nutrient balance estimates. On non-fertilized plots, $\mathrm{K}$ translocation from the subsoil by root action could also be expected, which tends to increase the $\mathrm{K}$ content of surface horizons through residue decomposition (McCallister et al. 1987). The soil available K content of our NP plots declined at a rate of $1.95 \mathrm{mg} \mathrm{K} \mathrm{O}_{2} \cdot \mathrm{kg}^{-1}$ soil $\cdot$ year ${ }^{-1}$. Plots fertilized with $75 \mathrm{~kg} \mathrm{~K}_{2} \mathrm{O} \cdot \mathrm{ha}^{-1}$ exhibited annual increases of available $\mathrm{K}_{2} \mathrm{O}$ of $3.70 \mathrm{mg} \cdot \mathrm{kg}^{-1}$ (NK treatment) to $4.04 \mathrm{mg} \cdot \mathrm{kg}^{-1}$ (NPK treatment). Plots that received the NPK + manure treatment showed a high rate of increase $-13.53 \mathrm{mg} \mathrm{K} \mathrm{O}_{2} \cdot \mathrm{kg}^{-1} \cdot \mathrm{y}^{-1}$.

Soil available $\mathrm{Ca}$ content in our experiments did not significantly change among different treatments $(p>0.05)$ (Table 3$)$. Ca concentration was the lowest in the NPK + manure plot (Table 3). These results differ from the data of Edmeades (2003) who reported that the use of manures relative to inorganic fertilizers result in soils becoming excessively enriched with some nutrients, including $\mathrm{Ca}$ and $\mathrm{Mg}$ in the topsoil. Our data also contradict findings of Mazur et al. (2015) who reported that multi-year mineral fertilization (NPK) led to the decrease in the content of $\mathrm{Ca}^{2+}$ in the sorption complex.

In our study, the available soil $\mathrm{Mg}$ in the unfertilized treatment was significantly higher than in the other plots (Table 3). The decrease of $\mathrm{Mg}$ in fertilized plots may be associated with much greater crop uptake of magnesium compared to control. Soil available Mg did not significantly vary among the treatments with mineral fertilization. The results of Vigovskis et al. (2015) also demonstrate that there were no relations between different rates of mineral fertilizers and magnesium and calcium content in soil.

Mobile iron concentration in the studied treatments was in the range of 6.1-8.5 mg $\cdot \mathrm{kg}^{-1}$ (Table 3). The long-term mineral fertilization had no detectable influence on the amount of available Fe in soil as compared to the control. The application of NPK + manure significantly increased DTPA extractable Fe. Our results agree with the findings of Moharana et al. (2017) who reported that plots receiving the FYM + NPK treatment maintained the highest amount of available $\mathrm{Fe}$ in surface soil $(0-15 \mathrm{~cm})$. This could be explained by the strong ability of organic matter to dissolve and complex with non-available micronutrients. As a result, available $\mathrm{Fe}$ usually increases as the amount of soil organic matter increases (Wei et al. 2006).

The available $\mathrm{Mn}$ content in the soil was 31.9 to $56.6 \mathrm{mg} \cdot \mathrm{kg}^{-1}$ (Table 3). The plot receiving the NPK + manure treatment had higher concentration of available Mn than the other treatments. According to Moharana et al. (2017), the lower $\mathrm{pH}$ may have resulted in the release of previously non-available $\mathrm{Mn}$ from soil minerals in the continuous FYM treatment. They also suggested that the decomposition of organic matter would have provided protons to the soil solution and also decreased soil Eh values and these changes could have resulted in the dissolution and reduction of Mn, thus, increasing its availability. Sim- 
ilarly, Li et al. (2007) reported that the organic fertilizer treatment had a higher concentration of DTPA-Mn than the other treatments and this may be due to the higher organic matter content in the organic fertilizer treated plots.

\section{CONCLUSIONS}

The long-term application of mineral fertilizers did not significantly change the soil $\mathrm{pH}$ reaction as compared to unfertilized control. The addition of manure $(\mathrm{NPK}+$ manure treatment) significantly decreased $\mathrm{pH}$. Different long-term fertilization treatments (mineral and organic-mineral fertilization) resulted in a substantial differentiation in soil humus and total N. Soil humus content in the NPK + manure treatment increased by $45.4 \%$ over the initial level. The humus depletion was by $5.0 \%$ to $12.2 \%$ with mineral fertilizers, and by $17.7 \%$ in the control plot as compared to the initial value. Long-term mineral phosphorus fertilization increased 5.5-5.7 times available $\mathrm{P}_{2} \mathrm{O}_{5}$ in the soil compared to the initial level. The soil available $\mathrm{K}_{2} \mathrm{O}$ content in NK and NPK treatments increased, respectively, by $41.1 \%$ and $44.9 \%$ over the initial level $\left(450.0 \mathrm{mg} \cdot \mathrm{kg}^{-1}\right.$ soil). A remarkable increase in available phosphorus (25.5 times) and potassium (2.5 times) content in the soil compared with the initial levels was found due to longterm NPK + manure fertilization. Availability of Fe and Mn in the soil was not significantly influenced by continuous mineral fertilization when compared to the control plot. There was significant increase of available Fe and Mn in treatment receiving NPK + manure. The NPK + manure treatment was found to be the most efficient management system in accumulating of total humus and $\mathrm{N}$, available $\mathrm{P}_{2} \mathrm{O}_{5}, \mathrm{~K}_{2} \mathrm{O}, \mathrm{Fe}$ and $\mathrm{Mn}$ in the $0-25 \mathrm{~cm}$ soil layer in the long-term fertilized Rendzic Leptosol, under a tobacco monocropping system.

\section{REFERENCES}

[1] Bhattacharyya, P., Nayak, A.K., Shahid, M., Tripathi, R., Mohanty, S., Kumar, A., Raja, R., Panda, B., Lal, B., Gautam, P., Swain, Ch.K., Roy, K.S., Dash, P.K., 2015. Effects of 42-Year Long-Term Fertilizer Management on Soil Phosphorus Availability, Fractionation, Adsorption-Desorption Isotherm and Plant Uptake in Flooded Tropical Rice. The Crop Journal, 3: 387-395. https://doi.org/10.1016/j.cj.2015.03.009.

[2] Debreczeni, K., Kismányoky, T., 2005. Acidification of Soil in Long-Term Field Experiments. Communications in Soil Science and Plant Analysis, 36: 321-329. https://doi.org/10.1081/ CSS-200043087.

[3] Debreczeni, K., Körschens, M., 2003. Long-Term Field Experiments of the World. Archives of Agronomy and Soil Science, 49: 465-483. https://doi.org/10.1080/03650340310001594754.

[4] Edmeades, D.C., 2003. The Long-Term Effects of Manures and Fertilisers on Soil Productivity and Quality: A Review. Nutrient Cycling in Agroecosystems, 66: 165-180. https://doi. org/10.1023/A:1023999816690. 
[5] Ellmer, F., Peschke, H., Köhn, W., Chmielewski, F.M., Baumecker, M., 2000. Tillage and Fertilizing Effects on Sandy Soils. Review and Selected Results of Long-Term Experiments at Humboldt University Berlin. Journal of Plant Nutrition and Soil Science, 163: 267-272. https://doi.org/10.1002/1522-2624(200006)163:3<267::AID-JPLN267>3.0.CO;2-Z.

[6] Goryanin, O., Chichkin, A., Dzhangabaev, B., Shcherbinina, E., 2019. Scientific Bases of the Humus Stabilization in Ordinary Chernozem in Russia. Polish Journal of Soil Science, 52: 113-128. 10.17951/pjss/2019.52.1.113.

[7] Hati, K.M., Swarup, A., Dwivedi, A.K., Misra, A.K., Bandyopadhyay, K.K., 2007. Changes in Soil Physical Properties and Organic Carbon Status at the Topsoil Horizon of a Vertisol of Central India after 28 Years of Continuous Cropping, Fertilization and Manuring. Agriculture, Ecosystems \& Environment, 119: 127-134. https://doi.org/10.1016/j.agee.2006.06.017.

[8] Jouany, C., Colomb, B., Bosc, M., 1996. Long-Term Effects of Potassium Fertilization on Yields and Fertility Status of Calcareous Soils of South-West France. European Journal of Agronomy, 5: 287-294. https://doi.org/10.1016/S1161-0301(96)02042-4.

[9] Kuo, S., Huang, B., Bembenek, R., 2005. Effects of Long-Term Phosphorus Fertilization and Winter Cover Cropping on Soil Phosphorus Transformations in Less Weathered Soil. Biology and Fertility of Soils, 41: 116-123. https://doi.org/10.1007/s00374-004-0807-6.

[10] Lenart, S., Kusinska, A., Gawronska-Kulesza, A., Nozderko, E., 2007. The Influence of LongTerm Fertilization and Soil Tillage System on Soil Organic Matter. Fragmenta Agronomica, 24: $150-156$.

[11] Li, B.Y., Zhou, D.M., Cang, L., Zhang, H.L., Fan, X.H., Qin, S.W., 2007. Soil Micronutrient Availability to Crops as Affected by Long-Term Inorganic and Organic Fertilizer Applications. Soil and Tillage Research, 96: 166-173. https://doi.org/10.1016/j.still.2007.05.005.

[12] Liang, Q., Chen, H., Gong, Y., Fan, M., Yang, H., Lal, R., Kuzyakov, Y., 2012. Effects of 15 Years of Manure and Inorganic Fertilizers on Soil Organic Carbon Fractions in a WheatMaize System in the North China Plain. Nutrient Cycling in Agroecosystems, 92: 21-33. https://doi.org/10.1007/s10705-011-9469-6.

[13] Lindsay, W., Norvell, W., 1978. Development of DTPA Soil Test for Zinc, Iron, Manganese and Copper. Soil Science Society of America Journal, 42: 421-428. https://doi.org/10.2136/ sssaj1978.03615995004200030009x.

[14] Mazumdar, S.P., Kundu, D.K., Ghosh, D., Saha, A.R., Majumdar B., Ghorai, A.K., 2014. Effect of Long-Term Application of Inorganic Fertilizers and Organic Manure on Yield, Potassium Uptake and Distribution of Potassium Fractions in the New Gangetic Alluvial Soil under Jute-Rice-Wheat Cropping System. International Journal of Agriculture and Food Science Technology, 5: 297-306. http://www.ripublication.com/ijafst.htm

[15] Mazur, Z., Sienkiewicz, S., Mazur, T., 2015. The Influence of Multi-Year Organic and Mineral Fertilisation on the Physicochemical Properties of Lessive Soil. Polish Journal of Soil Science, 48: 79-89. 10.17951/pjss/2015.48.1.79.

[16] McCallister, D.L., Shapiro, C.A., Raun, W.R., Anderson, F.N., Remh, G.W., Engelstad, O.P., Russelle, M.P., Olson, R.A., 1987. Rate of Phosphorus and Potassium Buildup/Decline with Fertilization for Corn and Wheat on Nebraska Mollisols. Soil Science Society of America Journal, 51: 1646-1652. https://doi.org/10.2136/sssaj1987.03615995005100060043x.

[17] Medinski, T., Freese, D., Reitz, T., 2018. Changes in Soil Phosphorus Balance and Phosphorus-Use Efficiency under Long-Term Fertilization Conducted on Agriculturally Used Chernozem in Germany. Canadian Journal of Soil Science, 98: 650-662. http://www.nrcresearchpress.com/doi/abs/10.1139/CJSS-2018-0061.

[18] Merbach, W., Garz, J., Schliephake, W., Stumpe, H., Schmidt, L., 2000. The Long-Term Fertilization Experiments in Halle (Saale), Germany - Introduction and Survey. Journal of Plant Nutrition and Soil Science, 163: 629-638. https://doi.org/10.1002/15222624(200012)163:6<629::AID-JPLN629>3.0.CO;2-P. 
[19] Moharana, P., Sharma, B., Biswas, D., 2017. Changes in the Soil Properties and Availability of Micronutrients after Six-Year Application of Organic and Chemical Fertilizers Using STCR-Based Targeted Yield Equations under Pearl Millet-Wheat Cropping System. Journal of Plant Nutrition, 40: 165-176. https://doi.org/10.1080/01904167.2016.1201504.

[20] Nardi, S., Morari, F., Berti, A., Tosoni, M., Giardini, L., 2004. Soil Organic Matter Properties after 40 Years of Different Use of Organic and Mineral Fertilisers. European Journal of Agronomy, 21: 357-367. https://doi.org/10.1016/j.eja.2003.10.006.

[21] Shevtsova, L., Romanenkov, V., Sirotenko, O., Smith, P., Smith, Jo U., Leech, P., Kanzyvaa, S., Rodionova, V., 2003. Effect of Natural and Agricultural Factors on Long-Term Soil Organic Matter Dynamics in Arable Soddy-Podzolic Soils - Modeling and Observation. Geoderma, 116: 165-189. https://doi.org/10.1016/S0016-7061(03)00100-9.

[22] Šimek, M., Hopkins, D.W., Kalčik, J., Picek, T., Šantrǔčková, H., Staňa, J., Trávnik, K., 1999. Biological and Chemical Properties of Arable Soils Affected by Long-Term Organic and Inorganic Fertilizer Applications. Biology and Fertility of Soils, 29: 300-308. https:// doi.org/10.1007/s003740050556.

[23] Sun, B., Cui, Q., Guo, Y., Yang, X., Zhang, S., Gao, M., Hopkins, D., 2018. Soil Phosphorus and Relationship to Phosphorus Balance under Long-Term Fertilization. Plant, Soil and Environment, 64: 214-220. https://doi.org/10.17221/709/2017-PSE.

[24] Teoharov, M., 2004. Correlation of Soils Indicated Map and Classification of Bulgaria with World Reference Base (WRBSR, 2002) (in Bulgarian). Soil Science Agrochemistry and Ecology, 39: 3-13.

[25] Tomov, T., Artinova, N., 2005. Effect of System Mineral and Organic-Mineral Fertilization on the Humus Content and Humus Fractions in Mollicfluvisols. Journal of Central European Agriculture, 6: 577-582.

[26] Tomov, T., Rachovsky, G., Kostadinova, S., Manolov, I., 1999. Manual for Agrochemistry (in Bulgarian). Academic Press of Higher Agricultural Institute, Plovdiv, p. 110.

[27] Totev, T., Gribachev, P., Nechev, H., Artinova, N., 1987. Manual for Soil Science (in Bulgarian). Zemizdat Sofia, p. 179.

[28] Vartanyan, A., 1979. The Systematic Mineral Fertilization and the Development of Oriental Tobacco and the Fertility of Soil (in Bulgarian). Bulgarian Tobacco, 10: 33-39.

[29] Vašák, F., Černý, J., Buráňová, Š.,Kulhánek, M., Balík, J., 2015. Soil pH changes in LongTerm Field Experiments with Different Fertilizing Systems. Soil \& Water Research, 10: 1923. 10.17221/7/2014-SWR.

[30] Vigovskis, J., Jermuss, A., Svarta, A., Sarkanbarde, D., 2015. The Changes of Nutrient Content in Soil in Long-Term Fertilizer Experiments. Proceedings of the $10^{\text {th }}$ International Scientific and Practical Conference on Environment, Technology and Resources, 18-20 June, Rezekne, Latvia, vol. 2, pp. 329-333.

[31] Wei, X., Hao, M., Shao, M., Gale, W.J., 2006. Changes in Soil Properties and the Availability of Soil Micronutrients after 18 Years of Cropping and Fertilization. Soil and Tillage Research, 91: 120-130. https://doi.org/10.1016/j.still.2005.11.009.

[32] Yang, S.M., Malhi, S.S., Li, F.M., Suo, D.R., Xu, M.G., Wang, P., Xiao, G.J., Jia, Y., Guo, T.W., Wang, J.G., 2007. Long-Term Effects of Manure and Fertilization on Soil Organic Matter and Quality Parameters of a Calcareous Soil in NW China. Journal of Plant Nutrition and Soil Science, 170: 234-243. https://doi.org/10.1002/jpln.200622012. 